\title{
Discovering new pathways in thrombus formation
}

Citation for published version (APA):

Nagy, M. (2019). Discovering new pathways in thrombus formation. [Doctoral Thesis, Maastricht University]. Gildeprint Drukkerijen. https://doi.org/10.26481/dis.20191107mn

Document status and date:

Published: 07/11/2019

DOI:

10.26481/dis.20191107mn

Document Version:

Publisher's PDF, also known as Version of record

\section{Please check the document version of this publication:}

- A submitted manuscript is the version of the article upon submission and before peer-review. There can be important differences between the submitted version and the official published version of record.

People interested in the research are advised to contact the author for the final version of the publication, or visit the DOI to the publisher's website.

- The final author version and the galley proof are versions of the publication after peer review.

- The final published version features the final layout of the paper including the volume, issue and page numbers.

Link to publication

\footnotetext{
General rights rights.

- You may freely distribute the URL identifying the publication in the public portal. please follow below link for the End User Agreement:

www.umlib.nl/taverne-license

Take down policy

If you believe that this document breaches copyright please contact us at:

repository@maastrichtuniversity.nl

providing details and we will investigate your claim.
}

Copyright and moral rights for the publications made accessible in the public portal are retained by the authors and/or other copyright owners and it is a condition of accessing publications that users recognise and abide by the legal requirements associated with these

- Users may download and print one copy of any publication from the public portal for the purpose of private study or research.

- You may not further distribute the material or use it for any profit-making activity or commercial gain

If the publication is distributed under the terms of Article $25 \mathrm{fa}$ of the Dutch Copyright Act, indicated by the "Taverne" license above, 
Summary 
Chapter 1 provides background information on mechanisms of blood platelet activation, collagen-induced thrombus formation and platelet-platelet interactions. Highlighted are the central roles of the collagen receptor glycoprotein VI (GPVI) and the signaling via cytosolic $\mathrm{Ca}^{2+}$ rises in these processes. Regarding thrombus formation on atherosclerotic plaques, an introduction is given of the known interactions of platelets with leukocyte subsets. This chapter also introduces the use of microfluidic devices for investigating the processes of thrombosis and hemostasis. Besides the Maastricht flow chamber employed in this thesis, also other custom-made and commercially devices are presented. Chapter $\mathbf{2}$ gives an overview of the use of such devices for the study of platelet activation and coagulation in flowed whole blood. Included is a guidance on technical aspects that need to be taken care of, when platelet and coagulation activities are simultaneously assessed in microfluidic devices. Choices encompass variables in the actual flow method, in the way of microscopic image capture, and in the kind of image analysis. Furthermore, the chapter provides an inventory of the current approaches for unraveling the mechanisms underlying platelet-dependent coagulation. Based on the described proof-of-principle studies with mouse and patient blood samples, the review also lists some limitations for the use of microfluidics assays in the clinical practice.

Given the importance of $\mathrm{Ca}^{2+}$ homeostasis for proper functioning of platelets and immune cells, Chapter $\mathbf{3}$ focuses on the regulation of cytosolic $\mathrm{Ca}^{2+}$ in these blood cells. Within the context of thrombosis and thrombo-inflammation, this chapter in particular focuses on the process of store-operated $\mathrm{Ca}^{2+}$ entry (SOCE). In blood cells, SOCE is the main mechanism by which extracellular $\mathrm{Ca}^{2+}$ enters especially via the $\mathrm{Ca}^{2+}$ channel ORAI1 and the intracellular $\mathrm{Ca}^{2+}$ sensor STIM1. How these two proteins interact and how they regulate the activities of platelets and immune cells is extensively described. The consequences are discussed of dysfunctional SOCE for pathophysiological processes such as atherothrombosis and ischemic stroke. Evidence for a role of ORAI1 and STIM1 in these processes comes from genetic mouse models and specific patients. Consistently, deficiency in ORAI1 or STIM1 leads to decreased thrombotic reactions without major bleeding complications, both in human and mouse. Given the limited role of platelet SOCE in normal hemostasis, inhibition of $\mathrm{Ca}^{2+}$ entry has been proposed as a new potential way to target thrombo-inflammatory diseases. However, pharmacological inhibitors tested so far have undesired side effects, in particular by influencing other cell types and tissues.

Genetic dysfunction of the SOCE-regulating proteins has been associated with development of immunodeficiency as well as with aberrant platelet functioning. In Chapter 4, the consequences of specific mutations in the ORAI1 or STIM1 genes are investigated for platelet activation and thrombus formation. While previous reports 
on platelets only examined individual patients, we were able to study a larger group of patients with a confirmed mutation in ORAI1 or STIM1. The platelets from most of these patients displayed altered $\mathrm{Ca}^{2+}$ signaling, when compared to control platelets. A loss-offunction mutation of ORAI1 led to a reduced SOCE, whereas a gain-of-function mutation in the channel tended to increase the SOCE signal. Interestingly, platelets from two patients with the same gain-of-function mutation in ORAl1 showed differences in the extent of SOCE. Blood samples from all patients were also evaluated using a multiparameter assay of thrombus formation, which provided detailed information on platelet adhesion, aggregation and activation on an array of thrombogenic surfaces. With blood from 4 out of 6 patients, parameters of thrombus formation on collagen were impaired, partly due to a lower platelet count. However, on other thrombogenic surfaces, the detected impairments in thrombus formation were independent of the platelet count, but were clearly associated with the SOCE abnormality. The dissimilar platelet responses seen in patients with the same ORAI1 mutation might be explained by a different penetration of the mutated ORAI1 allele in the bone marrow. Two young patients with a homozygous loss-of function mutation received a bone marrow transplantation, after which the flow test detected a clear improvement in platelet functioning. Overall, our study highlighted the ability of multi-parameter microfluidic testing to detect combined effects of quantitative and qualitative platelet abnormalities.

Earlier studies revealed that platelets and neutrophils interact during thrombosis and inflammation. In Chapter 5, we investigated how the platelets in a thrombus affected neutrophils. We found that the activation state of the platelets controlled the adhesion as well as the micro-location of neutrophils in a flow-dependent way. A stable thrombus consisting of thrombin-activated and procoagulant platelets was most effective in attracting neutrophils, which remained there for up to 16 hours. Adhesive receptors on activated platelets (CD62P, CD40L) mediated the interaction of neutrophils, whereas platelet secretion products steered neutrophil movements and activation processes. Strikingly, highly activated, secreting platelets induced patterns of repetitive intracellular $\mathrm{Ca}^{2+}$ rises in the attracted neutrophils. Silencing of platelets or blockage of platelet-derived chemokines (CCL5, CXCL7) caused an overall reduction of the $\mathrm{Ca}^{2+}$ rises, thus pointing to lower neutrophil activation stages. Heterogeneities in the thrombus structure influenced the movement patterns of neutrophils. Furthermore, using blood from Glanzmann patients, lacking the platelet integrin $\alpha_{111} \beta_{3}$, we detected a negative role of this integrin in neutrophil attraction. Taken together, these results pointed to a multi-step process of plateletneutrophil interactions, wherein glycoprotein receptors regulate neutrophil adhesion and platelet secretion products define the activation state of neutrophils in a thrombus. 
Genetic mouse models are frequently employed in cardiovascular research to study particular proteinsorsignaling pathwaysin platelets. Microfluidicschambersareextensively used for assessing altered platelet functions, but comparisons of studies have not been performed so far. In Chapter 6, a re-analysis is presented of microfluidic thrombus formation of whole blood from 38 different strains of genetically modified mice, such in comparison with blood from the corresponding wild type mice. The monogenetic knockout mice lacked a range of platelet receptors, protein kinases or other signaling proteins. In all cases, the studies were performed with the Maastricht flow chamber, the same experimental set up, and recording brightfield microscopic images. In this chapter, the images obtained from those experiments were uniformly re-analyzed to specifically assess alterations in platelet adhesion, aggregation and activation properties, according to a newly developed multiparameter approach. This re-analysis resolved high homogeneity of the results obtained with the various wild type mice, which then allowed us to also compare the modified mouse strains. Based on this multiparameter comparison, a network was constructed, unraveling the relative impact of the genes on thrombus formation and identifying clusters of genes implicated in GPVI-induced signaling. The unraveled phenotypic changes in vitro reflected well the alterations due to genetic knockout on arterial thrombosis tendency and tail bleeding in vivo. The multiparameter analysis allowed to judge on the severity of platelet defects regarding sub-processes of thrombus formation (platelet adhesion, aggregation and activation). Furthermore, for a subset of genes, also a comparison could be made of platelet-adhesive and signaling pathways induced by GPVI and other relevant adhesive receptors, such as C-type lectin like receptor 2 (CLEC2) and integrin $\alpha_{6} \beta_{1}$. Considering that thrombus formation in vivo is mediated not only by collagen, but also by other extracellular matrix proteins, we reasoned that the combination of multiple platelet-adhesive surfaces provides more complete insight into the consequences of platelet defects for arterial thrombosis.

Given the central role for GPVI in platelet activation and thrombus formation and its restricted expression in platelets with blood, GPVI is becoming a promising new target for antiplatelet therapy. In Chapter 7, we compared two small molecules, losartan and honokiol, with reported inhibitory effects on collagen-induced, GPVI-dependent platelet aggregation. While confirming this inhibition with GPVI ligands, we also noted inhibition when platelets were stimulated with a CLEC2 ligand. Furthermore, both compounds did not appear to affect platelet spreading nor GPVI clustering on the platelet membrane. However, losartan and honokiol suppressed platelet thrombus formation on a collagen surface. Jointly, these data indicated that these compounds are not acting as specific GPVI antagonists. Further studies are required to unravel the exact inhibitory mechanisms. 
In vivo mouse studies have revealed that arterial thrombi consist of separate inner core and outer shell regions, wherein the core region is crucial for stabilization of the thrombi. This stabilization is considered to rely on tight platelet-platelet contacts, which are mediated by integrins and gap junctional proteins. In Chapter 8, we investigated another possible way of inter-platelet contacts via the formation of tight junctions. Here, we focused on the localization of the tight junction protein, zona occludens 2 (ZO-2), which is abundantly expressed in platelets. Upon spreading, interacting platelets showed a redistribution of ZO-2 from the cytosol to the cell periphery. Ultimately, clusters of ZO-2 were seen at platelet-platelet contact sites, as demonstrated by high resolution confocal and super-resolution microscopy. Similar staining patterns for ZO-2 were also seen at sites of platelet-endothelial cell interactions, in a way resembling the structures between confluent endothelial cells. These first observations suggest that tight junctions of ZO-2 are formed between activated, interacting platelets, supporting their stable contacts.

Platelet reactivity can be increased in various diseases, such as obesity and diabetes mellitus. Since this hyperreactivity is associated with an increased risk of cardiovascular events, it is important to know the overall platelet functions in these patient groups. Chapter 9 investigates how a treatment with dipeptidyl peptidase 4 (DPP4) inhibitors - i.e. drugs regularly prescribed to diabetic patients - can influence platelet activity. Using various genetically modified mice, we found that abrogation of DDP4 by either pharmacological blockage or genetic deletion resulted in impaired thrombus formation. It is known that DPP4 inhibition leads to an increase in plasma of the bioactive form of glucagon-like peptide-1 (GLP1). We thus monitored how in vitro addition of bioactive GLP1 altered platelets. When added to human blood, GPL1 also resulted in a reduced thrombus volume. By contrast, the inactive form of GLP1 (i.e. the DPP4-cleaved GLP1) was without effect here. Interestingly, the GPL1 effect was only measurable in the presence of plasma or blood, suggesting that the presence of a plasma factor and perhaps flow is required for the inhibitory effect. We propose that in plasma the active GPL1 causes a negative priming effect on platelets, which results in a lower platelet activation capacity. These results provide new mechanistic insight into the cardioprotective effect of DPP4 inhibition in diabetic patients.

The final Chapter 10 discusses key findings of this thesis in view of the recent literature. It is reasoned that elaborate measurements of the thrombus-forming process using microfluidics techniques can disclose even small, relevant differences in the functions of human and murine platelets. 

Samenvatting 
Hoofdstuk 1 biedt relevante achtergrondinformatie over de mechanismen van plaatjesactivering, collageen-afhankelijke trombus-vorming en plaatjes-plaatjes interacties. Aandacht is besteed aan de centrale rol van de collageenreceptor glycoproteïne VI (GPVI) en de signalering door verhoging van het cytosolisch $\mathrm{Ca}^{2+}$ in deze processen. Beschreven is verder op welke wijzen bloedplaatjes een interactie kunnen aangaan met verschillende typen leukocyten bij de trombusvorming op atherosclerotische plaques. Dit hoofdstuk geeft voorts aan hoe microfluidic kamers gebruikt kunnen worden bij de bestudering van trombose- en hemostaseprocessen. Naast de Maastricht flow-kamer gebruikt in dit proefschrift, worden ook andere al dan niet commercieel verkrijgbare kamers gepresenteerd. Hoofdstuk 2 geeft een overzicht van het gebruik van dergelijke kamers voor bepalingen van de plaatjesactivering en de stolling in stromend bloed. Richtlijnen zijn gegeven voor de technische procedures die gevolgd kunnen worden om degelijke metingen succesvol te kunnen verrichten. Keuzes moeten gemaakt worden wat betreft de flow-methode, de wijze van microscopie en beeldvorming, en de procedure van beeldanalyse. Dit hoofdstuk beschrijft verder de mogelijke experimentele benaderingen voor het ophelderen van de mechanismen van plaatjes-afhankelijke bloedstolling. Op basis van enige proof-of-principle studies met bloed van muizen of patiënten wordt ook ingegaan op de beperkingen van het gebruik van microfluidic testen in de klinische praktijk.

Een goede $\mathrm{Ca}^{2+}$ homeostase is van essentieel belang voor het adequaat functioneren van plaatjes en immuuncellen. Hoofdstuk 3 geeft een overzicht van de regulatie van de cytosolische $\mathrm{Ca}^{2+}$-concentratie in dergelijke bloedcellen. Met als aandachtspunten trombose en ontsteking gaat dit hoofdstuk uitgebreid in op het proces van store-operated $\mathrm{Ca}^{2+}$ entry (SOCE). In bloedcellen is SOCE het belangrijkste mechanisme waardoor $\mathrm{Ca}^{2+}$ van buiten de cel binnenkomt via het $\mathrm{Ca}^{2+}$-kanaal ORAl1 en de intracellulaire $\mathrm{Ca}^{2+}$-sensor STIM1. Beschreven is hoe deze twee eiwitten een interactie met elkaar aangaan, en hoe zij tezamen de activeringspatronen van plaatjes en immuuncellen bepalen. Ook is aangegeven welke de gevolgen zijn van een verstoorde SOCE bij de pathofysiologie van atherotrombose en een ischemisch herseninfarct. De aanwijzingen voor een rol van ORAI1 en STIM1 bij deze processen komen uit studies met genetische gemodificeerde muizen en met specifieke patiëntengroepen. Een defecte werking van ORAI1 of STIM1 resulteert in een verminderde tromboseneiging, echter zonder grote bloedingscomplicaties zowel bij mens als muis. Gezien de beperkte rol van SOCE bij de normale hemostase is er verondersteld dat remming van de $\mathrm{Ca}^{2+}$-instroom een manier kan zijn 
om te interveniëren bij trombotische aandoeningen. Evenwel blijken de farmacologische remmers die tot dusver zijn getest, ongewenste bijeffecten te hebben als gevolg van beïnvloeding van andere cellen en weefsels.

Mutaties in de eiwitten die SOCE reguleren kunnen gepaard gaan met immuundefecten dan wel met functieverlies van bloedplaatjes. In Hoofdstuk $\mathbf{4}$ zijn de gevolgen onderzocht van mutaties in de ORAI1 of STIM1 genen voor de plaatjesactivering en trombusvorming. In tegenstelling tot eerder werk, waarin alleen enkele patiënten gerapporteerd zijn, konden wij hier een grotere groep patiënten bestuderen, allen met dysfunctionele mutaties in ORAI1 of STIM1. De plaatjes van de meesten van deze patiënten vertoonden een abnormaal $\mathrm{Ca}^{2+}$-signaal in vergelijking tot controleplaatjes. Een loss-of-function mutatie in ORAI1 resulteerde in een verminderde SOCE, terwijl een gain-of-function mutatie in dit kanaal soms een verhoogd SOCE-signaal liet zien. Een markante bevinding was dat de plaatjes van twee patiënten met dezelfde gain-offunction mutatie in ORAI1 verschilden in de mate van SOCE-activiteit. Het bloed van al deze patiënten werd ook gebruikt voor bepaling van de trombusvorming. Hiervoor werd een multiparameter-test gebruikt, die detail informatie geeft over de adhesie, aggregatie en activering van plaatjes op verschillende trombogene oppervlakken. Bij bloed van 4 van de 6 patiënten bleek de trombusvorming op een collageenoppervlak verminderd te zijn, ten dele als gevolg van een matig verlaagde plaatjesconcentratie. Anderzijds was de verminderde trombusvorming op andere oppervlakken onafhankelijk van de lagere plaatjesconcentratie, en was deze duidelijker gelinkt aan het SOCE-defect. De waargenomen verschillen in plaatjesreactiviteit tussen patiënten met eenzelfde ORAI1 mutatie kan verklaard worden door een ongelijke penetratie van het gemuteerde ORAl1 allel in het beenmerg. Twee jonge patiënten (kinderen) met een homozygote loss-of function mutatie ondergingen een beenmergtransplantatie, waarna dezelfde flowtest een duidelijke verbetering toonde van het plaatjesfunctieprofiel. Samengevat demonstreert deze studie de mogelijkheden van multiparameter testen met behulp van flow-kamers bij het opsporen van gecombineerde effecten van kwantitatieve en kwalitatieve plaatjesafwijkingen.

Eerder werk heeft laten zien dat plaatjes en granulaire leukocyten (neutrofielen) met elkaar interacties kunnen aangaan bij tromboses en ontstekingen. In Hoofdstuk 5 hebben we onderzocht op welke wijze de plaatjes in een trombus invloed kunnen uitoefenen op naburige neutrofielen. Het bleek dat de activeringsstatus van de plaatjes bepalend was voor de aanhechting en de micro-locatie van neutrofielen uit bloed op een flow-afhankelijke manier. Een stabiele trombus opgebouwd uit trombine-geactiveerde en procoagulante plaatjes was meest effectief in het aantrekken van neutrofielen, die vervolgens tot 16 
uur ter plekke bleven. Adhesieve receptoren op geactiveerde plaatjes (CD62P, CD40L) bewerkstelligden de hechting van neutrofielen, terwijl secretieproducten van plaatjes een sturende werking hadden op de bewegingspatronen en activeringsprocessen van de neutrofielen. Met name sterk geactiveerde, secreterende plaatjes zorgden voor een patroon van herhaalde $\mathrm{Ca}^{2+}$-verhogingen in naburige neutrofielen. Wanneer de plaatjes tot rust gebracht werden of wanneer chemokines afkomstig uit de plaatjes geblokkeerd werden (CCL5, CXCL7), gaf dit een vermindering van de $\mathrm{Ca}^{2+}$-responsen, en als gevolg daarvan een verlaagde activeringsstatus van de neutrofielen. Onregelmatigheden in trombusstructuur waren van invloed op de bewegingspatronen van de witte bloedcellen. Verder vonden we, gebruik makend van het bloed van Glanzmann patiënten - bij wie integrine $\alpha_{\| 1} \beta_{3}$ op plaatjes ontbreekt -, dat dit integrine een negatieve rol had bij het aantrekken van neutrofielen. Samengevat wijzen de resultaten in dit hoofdstuk op een multi-stap proces van neutrofiel-plaatjes interacties, waarin glycoproteïne-receptoren bepalend zijn voor de neutrofiel-adhesie en plaatjes-secretieproducten zorg dragen voor een verhoogde activeringsstatus van de neutrofielen in een trombus.

In het cardiovasculaire onderzoek worden genetische gemodificeerde muizen veelvuldig gebruikt om specifieke eiwitten of signaleringspaden in plaatjes te bestuderen. Flow-kamers worden daarbij regelmatig toegepast om veranderingen vast te stellen in de plaatjeseigenschappen. Echter een goede vergelijking van dergelijke studies ontbreekt nog. Hoofdstuk 6 bestaat uit een hernieuwde analyse van eerder werk, waarin de trombusvorming middels flow-kamers bepaald was met bloed van 38 verschillende stammen van genetisch gemodificeerde muizen, die steeds onderzocht waren in vergelijking met bloed van bijbehorende wildtype-muizen. De betreffende knockoutmuizen hadden alle een mono-genetische deficiëntie in plaatjes-receptoren, proteïnekinasen of andere signaleringseiwitten. In alle gevallen waren de oorspronkelijke studies uitgevoerd met dezelfde Maastricht flow-kamer, gebruik makend van dezelfde experimentele opzet, en van camera-opnames van microscopische helderveld-beelden. Beschreven is hoe de microscopie-beelden opnieuw zijn geanalyseerd om een beter inzicht te krijgen in de veranderingen in plaatjesadhesie, -aggregatie en -activering, daarbij gebruik makend van nieuwe multiparameter analysemethoden. Wij vonden sterk gelijkende resultaten voor de verschillende wildtype-muizen, waarmee het mogelijk werd om ook de genetisch gemodificeerde muizen onderling te vergelijken. Middels vergelijking van de diverse parameters konden we een netwerk van genen construeren, waarmee enerzijds beter inzicht verkregen werd in het relatieve belang van betreffende genen voor de trombusvorming, en anderzijds genenclusters naar voren kwamen, betrokken bij 
de GPVI-afhankelijke signalering. De aldus bepaalde fenotypische veranderingen bleken goed overeen te komen met de effecten van genetische modificatie in vivo op de arteriële tromboseneiging en op staartbloedingstijden. Daarmee is deze multiparameter-analyse in staat een uitspraak te doen over de mate van plaatjesdysfunctie voor wat betreft subprocessen van trombusvorming (plaatjesadhesie, -aggregatie en -activering). Voorts kon voor een aantal genen ook een vergelijking gemaakt worden tussen signaleringsroutes, die gemedieerd worden door GPVI, C-type lectin like receptor 2 (CLEC2) of integrine $\alpha_{6} \beta_{1}$. Aangezien trombusvorming in vivo niet uitsluitend door collageen maar ook door andere extracellulaire matrixeiwitten gemedieerd wordt, stipuleren wij dat de combinatie van plaatjes-adhesieve oppervlakken een meer compleet inzicht geeft in de gevolgen van plaatjesdefecten voor de arteriële trombose.

Uitgaande van een centrale rol van GPVI bij de plaatjesactivering en trombusvorming - een eiwit dat in bloed alleen in plaatjes tot expressie komt - , is het duidelijk dat GPVI wordt beschouwd als een veelbelovende nieuwe target voor antiplaatjestherapie. In Hoofdstuk 7 hebben wij twee moleculen vergeleken, losartan en honokiol, waarvan een remmend effect beschreven is van de collageen-geïnduceerde en GPVI-afhankelijke plaatjesaggregatie. Deze waarnemingen konden wij bevestigen. Echter daarnaast maten we een inhibitie na stimulering van de plaatjes met CLEC2-ligand. Beide moleculen hadden geen effect op de spreiding van plaatjes of op de clustering van GPVI op het plaatjesmembraan. Echter zowel losartan als honokiol onderdrukten de trombusvorming op collageen. Tezamen geven deze bevindingen aan dat de betreffende moleculen niet werkzaam zijn als specifieke GPVI-antagonisten. Verder onderzoek is nodig om de precieze remmingsmechanismen te bepalen.

Experimenten met muizen in vivo hebben aangetoond dat arteriële trombi opgebouwd zijn uit een binnenste compacte structuur en daarbuiten een schil van los geaggregeerde plaatjes. Hierbij blijkt de binnen laag cruciaal te zijn voor de trombusstabilisatie. Deze stabilisatie wordt bewerkstelligd door vaste plaatjes-plaatjes contacten onder meer middels integrines en gap-junction eiwitten. In Hoofdstuk 8 exploreerden we een aanvullend mechanisme van contactvorming tussen plaatjes, namelijk via de vorming van tight-junctions. Het onderzoek was vooral gericht op de subcellulaire lokalisatie van het tight-junction eiwit zona occludens 2 (ZO-2), welke in hoge mate tot expressie komt in plaatjes. Plaatjes die spreidden en daarmee met elkaar in contact kwamen, lieten een herverdeling zien van het ZO-2 van het cytosol naar de celperiferie. Hoge resolutie confocale microscopie en super-resolutie microscopie onthulden de vorming van ZO-2 clusters in de contactplaatsen. Een soortgelijk kleuringspatroon 
voor ZO-2 was ook aanwezig op contactplaatsen plaatjes met endotheelcellen, analoog aan de structuren tussen confluente endotheelcellen. Deze bevindingen suggereren dat er tussen geactiveerde, contact-makende plaatjes tight-junctions van ZO-2 gevormd worden, die van belang zijn voor stabiele plaatjes-plaatjes interacties.

De activiteit van plaatjes is vaak verhoogd bij aandoeningen als obesitas en diabetes mellitus. Aangezien een dergelijke hyperreactiviteit associeert met een verhoogd risico op hart- en vaatziekten, is het van belang om de plaatjesfuncties in deze patiëntengroepen goed te kennen. Hoofdstuk 9 beschrijft hoe behandeling met remmers van dipeptidyl peptidase 4 (DPP4) - medicatie die regelmatig wordt voorgeschreven aan diabetici - van invloed is op de plaatjesactiviteit. Gebruik makend van genetisch gemodificeerde muizen konden wij vaststellen, dat een defect in DDP4 middels een farmacologische remmer of genetische modificatie, resulteerde in verminderde trombusvorming. Bekend was dat de remming van DPP4 leidt tot een toename in plasma van de bioactieve vorm van glucagonlike peptide-1 (GLP1). Daarom onderzochten wij het effect van toevoeging van bioactief GLP1 op plaatjes in vitro. In humaan bloed zorgde GPL1 voor een kleiner trombusvolume. Daarentegen was de inactieve vorm van GLP1 (d.w.z. het DPP4-geknipt GLP1) zonder effect. Een verdere interessante bevinding was dat het bioactieve GPL1 alleen werkzaam was in de aanwezigheid van plasma of bloed, hetgeen suggereert dat er een plasmafactor (of ook flow) nodig is voor het remmende effect. Daarmee konden we postuleren, dat in de aanwezigheid van plasma het actieve GPL1 voor een negatief priming effect op plaatjes zorgt, waardoor de plaatjesactivering verlaagt. Deze resultaten bieden daarmee een mechanistisch inzicht in de manier waarop DDP4-remming beschermend kan zijn voor cardiovasculaire aandoeningen in patiënten met diabetes.

Het laatste Hoofdstuk $\mathbf{1 0}$ bediscussieert de belangrijkste bevindingen van deze dissertatie, gezien de recente literatuur. Beargumenteerd is dat uitgebreide analyse van het proces van trombusvorming met behulp van microfluidic technieken zelfs kleine, relevante verschillen kan detecteren in de functies van humane en muizenplaatjes. 